\section{Probing RNA Structure with Chemical Reagents and Enzymes}

The function of an RNA molecule in vivo and in vitro will often depend on its tertiary structure as well as the information encoded in its Watson-Crick base-pairing potential. There are now a number of powerful methods that can be used simultaneously to determine structural properties of small and large RNAs. This unit and subsequent units provide methods for RNA footprinting, detecting positions sensitive to chemical and enzymatic attack in the presence or absence of bound proteins. RNA footprinting differs profoundly from DNA footprinting in that the starting structure of the RNA cannot be taken for granted even in general terms, and the footprinting reactions are often carried out with structure-sensitive reagents precisely for the purpose of elucidating the RNA solution structure. When interpreting these structures, however, it is necessary to always consider whether the functional form of the RNA molecule is being examined.

The first four protocols in this unit provide methods for modifying and cleaving RNA for the purpose of probing structure. Three of these protocols use structure-sensitive chemicals - dimethyl sulfate (DMS; see Basic Protocol 1), diethylpyrocarbonate (DEPC; see Alternate Protocol 1), and ethylnitrosourea (ENU; see Alternate Protocol 2). The fourth describes the use of various nucleases (see Table 6.1.1) to probe RNA structure (see Basic Protocol 2). Three other protocols can be used together to analyze the base-pairing status of RNA. The reagents modify Watson-Crick positions of nucleotides not involved in base pairing or tertiary hydrogen bonding. Dimethyl sulfate (see Basic Protocol 3) is used to probe unpaired adenines and cytidines, while kethoxal (see Alternate Protocol 3) and 1-cyclohexyl-3-(2-morpholinoethyl)carbodiimide metho- $p$-toluenesulfonate (CMCT; see Alternate Protocol 4) are used to investigate unpaired guanosines and uridines, respectively. RNA cleavages and base modifications can be detected by primer extension (see Support Protocol 4), or cleavage sites can be detected by using RNA that has been labeled at the $5^{\prime}$ terminus with T4 polynucleotide kinase (see Support Protocol 1) or the $3^{\prime}$ terminus by T4 RNA ligase (see Support Protocol 2). Support Protocol 3 details the preparation of electrophoresis standards for use with end-labeled RNA.

CAUTION: When working with radioactivity, take appropriate precautions to avoid contamination of the experimenter and the surroundings. Carry out the experiment and dispose of wastes in an appropriately designated area, following the guidelines provided by the local radiation safety officer.

NOTE: Experiments involving RNA require careful precautions to prevent contamination and RNA degradation (see APPENDIX 2A).

\section{STRATEGIC PLANNING}

\section{Footprinting with an Appropriate RNA}

Before undertaking these often labor-intensive footprinting experiments it is worthwhile to evaluate the extent to which all or most of the RNA sample to be examined is in an appropriate folded state (see Critical Parameters; for general guidelines for RNA folding, see UNIT 6.3). There are a number of ways of determining this when the RNA is to be probed in vitro; the method used depends on which experimental system is available to assess the structure of the RNA. In the simplest case, the RNA might have an assayable function that can be demonstrated in vitro. An example of this is an artificial RNA ligand selected for binding to a protein target in vitro. RNAs isolated from cells are generally more

Contributed by William A. Ziehler and David R. Engelke Current Protocols in Nucleic Acid Chemistry (2000) 6.1.1-6.1.21

Copyright $(2000$ by John Wiley \& Sons, Inc.
Chemical and Enzymatic Probes for Nucleic Acid Structure 
Table 6.1.1 RNA Structure-Probing Reagents and Their Specificities

\begin{tabular}{|c|c|c|c|}
\hline Reagent $^{a}$ & Target $^{b}$ & Where discussed & Supplier \\
\hline \multicolumn{4}{|l|}{ For cleavage: } \\
\hline $\mathrm{DMS}^{c}$ & ss or ds G (N7) & Basic Protocol 1 & Aldrich \\
\hline $\mathrm{DEPC}^{c}$ & ss or ds A (N7) & $\begin{array}{l}\text { Alternate } \\
\text { Protocol } 1\end{array}$ & Sigma \\
\hline $\mathrm{ENU}^{c}$ & Phosphate oxygens & $\begin{array}{l}\text { Alternate } \\
\text { Protocol } 2\end{array}$ & Sigma \\
\hline Hydroxyl radicals & Ribose sugar backbone & UNIT 6.5 & \\
\hline $\mathrm{Pb}^{2+}$ & $\begin{array}{l}\text { Phosphates of ss } \\
\text { nucleotides }\end{array}$ & UNIT 6.3 & \\
\hline Mung bean nuclease ${ }^{d}$ & ss N/pN & Basic Protocol 2 & Roche or Promega \\
\hline RNase A & ss $\mathrm{Cp} / \mathrm{N}$ and $\mathrm{Up} / \mathrm{N}$ & Basic Protocol 2 & Roche \\
\hline RNase CL3 & ss $\mathrm{Cp} / \mathrm{N}$ & Basic Protocol 2 & USB \\
\hline RNase I(ONE) & ss $\mathrm{Np} / \mathrm{N}$ & Basic Protocol 2 & Promega (RNase ONE) \\
\hline RNase Phy M & ss $A p / N$ and $U p / N$ & Basic Protocol 2 & Pharmacia \\
\hline RNase T1 & ss $\mathrm{Gp} / \mathrm{N}$ & Basic Protocol 2 & Life Technologies \\
\hline RNase $\mathrm{T} 2$ & ss $\mathrm{Np} / \mathrm{N}$ & Basic Protocol 2 & Life Technologies \\
\hline RNase U2 & ss Ap/N & Basic Protocol 2 & Pharmacia \\
\hline $\mathrm{RNase} \mathrm{V} 1^{d}$ & ds N/pN & Basic Protocol 2 & Pharmacia \\
\hline S1 nuclease ${ }^{d}$ & ss N/pN & Basic Protocol 2 & Roche or Promega \\
\hline \multicolumn{4}{|l|}{ For modification: } \\
\hline CMCT & $\begin{array}{l}\text { Primarily U (N3) and } \\
\text { possibly G (N1) }\end{array}$ & Alternate Protocol 4 & Aldrich \\
\hline DMS & $\mathrm{A}(\mathrm{N} 1)$ and $\mathrm{C}(\mathrm{N} 3)$ & Basic Protocol 3 & Aldrich \\
\hline Kethoxal & $\mathrm{G}\left(\mathrm{N} 1,2-\mathrm{NH}_{2}\right)$ & Alternate Protocol 3 & $\begin{array}{l}\text { ICN or Research } \\
\text { Organics }\end{array}$ \\
\hline
\end{tabular}

${ }^{a}$ Abbreviations: CMCT, 1-cyclohexyl-3-(2-morpholinoethyl)carbodiimide metho- $p$-toluenesulfonate; DEPC, diethylpyrocarbonate; DMS, dimethyl sulfate; ds, double-stranded; ENU, ethylnitrosourea; ss, single-stranded.

${ }^{b}$ Cleavage site indicated by shill. Specific position of cleavage or modification are indicated in parentheses.

${ }^{c}$ This reagent requires further chemical processing to cleave the RNA.

${ }^{d}$ Nuclease requires divalent cations for activity. For $\mathrm{RNase} \mathrm{V} 1, \mathrm{MgCl}_{2}(10 \mathrm{mM}$ final) is recommended, mung bean nuclease and $\mathrm{S} 1$ nuclease require zinc acetate as per supplier's instructions.

Probing RNA

Structure with Chemical

Reagents and Enzymes

difficult to interpret. If an RNA is stripped of its native protein structure in the process of being isolated from cells, or if an RNA is made synthetically, it should be assumed that the folding of that RNA is suspect until proven otherwise. Small RNAs that are tightly structured, such as tRNAs, can often refold in functional form, but this cannot be assumed. The chances of misfolding increase dramatically for larger RNAs where there are more potential isoforms. An RNA that is isolated as part of a ribonucleoprotein (RNP) complex, such as a ribosomal subunit, is generally assumed to be correctly folded, but even that assumption should be viewed with caution.

\section{Choice of Structure-Sensitive Reagents}

The object in RNA footprinting is to determine which positions in the RNA are accessible to specific types of attack by chemical reagents or nucleases. Cleavage or modification by these reagents is normally performed under conditions where the target RNA is cleaved at most once per molecule, thus lowering the chance that the first cleavage/modification causes an RNA rearrangement that alters access for a second attack. The cleavage or modification specificities of individual nucleases and commonly used chemicals are listed in Table 6.1.1. It is worth considering the general advantages and disadvantages of different classes of reagents. Nucleases have the lowest resolution because their steric radii do not allow access to many sites that are solvated; however, they are easily used in a wide range of physiological buffers. Most of the nucleases described below are specific 
for nucleotides not involved in Watson-Crick pairing, with variable sensitivity to other types of structure and base specificity. The exception is cobra venom ribonuclease (V1), which is the only reagent described here that is specific for double-stranded regions. Even V1 is not exceptionally helpful in identifying double-stranded structures, however, because the ability of V1 to cleave helices is variable. Cleavage by V1 is infrequent, and V1 can cleave adjacent to rather than within helices.

The available chemical reagents discussed in this and subsequent units allow better access to all regions of the RNA tertiary structure and cumulatively attack a wide range of nucleotide positions. In general, using a larger number of different reagents to probe allows a more detailed view of solvent-exposed positions. Exposure of phosphates, sugars, and aromatic ring positions can be probed. Reagents specific for Watson-Crick positions are often used as diagnostics for the existence of standard base pairing at contiguous nucleotides. Some of the protocols described below are based on methods described previously (Peattie and Gilbert, 1980; Knapp, 1989; Krol and Carbon, 1989).

Location of chemical and nuclease cleavages can be determined using end-labeled RNA or primer extension. Hydroxyl radicals (UNIT 6.5) and $\mathrm{Pb}^{2+}$ (UNIT 6.3) will directly hydrolyze the phosphodiester backbone, as will the various nucleases according to their sequence and structural preferences. Other reagents, including DMS, DEPC, and ENU, require additional chemical steps, ultimately resulting in strand scission.

\section{Detection of Modifications or Cleavage Sites}

The method used to detect cleavages or modified positions varies with both the nature of the RNA being probed and the reagents being used. Short RNAs ( $<200$ nucleotides) can be labeled at either the $5^{\prime}$ or $3^{\prime}$ end (Support Protocols 1 and 2), then folded and subjected to reagents that result in RNA strand cleavage. Separation of the cleaved RNA on denaturing polyacrylamide gels and determination of fragment sizes identifies the position of cleavage sites. Alternatively, a labeled DNA oligomer primer can be annealed at any point along the length of an unlabeled RNA and extended to a point of cleavage or Watson-Crick base modification (Support Protocol 4). Either case terminates extension and produces a labeled DNA fragment corresponding to the length from the label to the termination site. There are a variety of labels that can be used with these two general detection schemes. The most common label is ${ }^{32} \mathrm{P}$, which can be detected with either X-ray film or a phosphorimager.

The question of whether to use end labeling or primer extension for detection depends on the RNA to be analyzed and how many reagents are needed. Primer extension is more often useful for longer RNAs, although end labeling is still widely used to probe small RNAs. The advantage of end labeling is that it requires fewer manipulations (i.e., no primer-extension reactions) after the cleavage reactions. Its disadvantages include that it can only be used for relatively short RNAs that can be labeled before cleavage reagent treatment and that it requires cleavage of the RNA strand for detection. Transfer RNAs, 5S rRNAs, and other small, structured RNAs have typically been investigated by end labeling.

Primer extension has four main disadvantages. The first is that the extreme $3^{\prime}$ end of the RNA cannot be probed because the primer must anneal to the $3^{\prime}$ side of the region to be extended across. The second disadvantage is that sequence-dependent pausing and termination by the reverse transcriptase, even on intact RNA, tends to give a high background at some positions that obscures the true signal from cleavage or modification. This problem can be reduced by using different reverse transcriptases and/or extension conditions, but is never completely eliminated with structured RNAs. The third disadvan-

Chemical and Enzymatic Probes for Nucleic Acid Structure 
BASIC PROTOCOL 1

Probing RNA

Structure with Chemical

Reagents and Enzymes tage is that additional manipulations are required to perform the primer-extension reactions following the cleavage or modification reactions. Finally, cellular RNAs may contain posttranscriptional modifications that will terminate the extension reaction. However, primer-extension RNA footprinting is potentially useful in many situations. For example, RNA of any size can be probed because a labeled primer can be placed anywhere along the length of RNA, and multiple primers can be used in separate reactions to detect cleavages or modifications along the entire length. The RNA also does not need to be purified or labeled in advance, allowing probing of preformed RNA-protein complexes even in crude cell lysates. Following the cleavage/modification reactions, protein is removed by organic extraction and the purified RNA is subjected to primer extension. Lastly, the extension reactions can be used to detect several chemical modifications at Watson-Crick positions in addition to any form of RNA strand cleavage.

\section{MODIFICATION AND CLEAVAGE OF RNA USING DIMETHYL SULFATE}

Dimethyl sulfate (DMS) alkylates the N7 cyclic amine of guanosine. The methylated nucleoside is reduced, opening the imidizole ring and weakening the glycosidic bond. Aniline treatment catalyzes the $\beta$-elimination of the ribose sugar, leaving the nucleotide $5^{\prime}$ of the displaced guanosine with a $3^{\prime}$ phosphate and the nucleotide $3^{\prime}$ of the guanosine with a $5^{\prime}$ phosphate. The $\mathrm{N7}$ position is pointed into the major groove of an A-form RNA helix and is accessible to modification. Therefore, the N7 of double-stranded and single-stranded guanosines should be detected unless participating in tertiary structure or non-Watson-Crick base-pair interactions. See Strategic Planning for a discussion of choice of RNA, folding, and detection methods.

\section{Materials}

1 M HEPES, $\mathrm{pH} 7.8$

$1 \mathrm{M} \mathrm{KCl}$

$0.1 \mathrm{M} \mathrm{MgCl}_{2}$

$1 \mu \mathrm{g} / \mu \mathrm{L}$ carrier RNA (see recipe)

Sample RNA, end labeled (see Support Protocol 1 or Support Protocol 2) or unlabeled

RNase-free water (see recipe)

$\geq 99 \%$ dimethyl sulfate (DMS) (Aldrich)

$3 \mathrm{M}$ sodium acetate, $\mathrm{pH} 5.2$ (APPENDIX 2A)

$100 \%$ and $70 \%(\mathrm{v} / \mathrm{v})$ ethanol

$1 \mathrm{M}$ Tris. $\mathrm{Cl}, \mathrm{pH} 8.0$ (APPENDIX 2A)

$0.2 \mathrm{M} \mathrm{NaBH}_{4}$, prepared fresh

$1 \mathrm{M}$ aniline acetate buffer (see recipe)

FEXS solution (see recipe; for end-labeled RNA)

Additional reagents and equipment for denaturing polyacrylamide gel electrophoresis (e.g., APPENDIX $3 B$ or CPMB UNIT 2.12) or primer extension (see Support Protocol 4)

NOTE: DMS is highly toxic and a suspected carcinogen; use appropriate precautions for handling, storage, and disposal.

\section{Methylate guanosine N7}

1. Prepare reaction mix as follows:

$8 \mu \mathrm{L} 1 \mathrm{M}$ HEPES, pH 7.8 (final $200 \mathrm{mM}$ )

$4 \mu \mathrm{L} 1 \mathrm{M} \mathrm{KCl}(100 \mathrm{mM})$

$4 \mu \mathrm{L} 0.1 \mathrm{M} \mathrm{MgCl}_{2}(10 \mathrm{mM})$

$8 \mu \mathrm{L} 1 \mu \mathrm{g} / \mu \mathrm{L}$ carrier RNA $(0.2 \mu \mathrm{g} / \mu \mathrm{L})$. 
2. Combine 50,000 cpm end-labeled sample RNA or $0.5 \mu \mathrm{g}$ unlabeled sample RNA (for primer extension) with RNase-free water to make $15 \mu \mathrm{L}$ total and add to reaction mix.

3. Add $1 \mu \mathrm{L}$ of $99+\%$ DMS, mix, and incubate 2 min at room temperature.

4. Stop the reaction by precipitating with $4 \mu \mathrm{L}$ of $3 \mathrm{M}$ sodium acetate and $120 \mu \mathrm{L}$ of $100 \%$ ethanol on dry ice. Microcentrifuge $30 \mathrm{~min}$ at maximum speed (10,000 rpm), $4^{\circ} \mathrm{C}$. Remove supernatant, rinse with $70 \%$ ethanol, and dry the pellet in a speedvac.

\section{Reduce methylated RNA and perform aniline cleavage}

5. Resuspend pellet with $20 \mu \mathrm{L}$ of $1 \mathrm{M}$ Tris. $\mathrm{Cl}$ and $20 \mu \mathrm{L}$ of $0.2 \mathrm{M} \mathrm{NaBH}_{4}$.

6. Incubate $30 \mathrm{~min}$ on ice in the dark.

7. Precipitate as in step 4.

8. Resuspend pellet in $40 \mu \mathrm{L}$ of $1 \mathrm{M}$ aniline acetate buffer and incubate $15 \mathrm{~min}$ in the dark at $60^{\circ} \mathrm{C}$.

9. Precipitate as in step 4.

10. If end-labeled RNA was used, resuspend in $12 \mu \mathrm{L}$ FEXS solution and proceed with direct gel electrophoresis (e.g., APPENDIX $3 B$ ). If RNA sample was unlabeled, see Support Protocol 4 and perform primer extension.

See Support Protocol 3 for preparation of appropriate end-labeled RNA standards for electrophoresis.

\section{MODIFICATION AND CLEAVAGE OF RNA USING DIETHYLPYROCARBONATE}

Diethylpyrocarbonate (DEPC) alkylates the N7 cyclic amine of adenosine. The mechanism and procedure are essentially identical to those described for DMS (see Basic Protocol 1), except that DEPC is used and the incubation time is increased (replace step 3 in Basic Protocol 1 with the following step). See Strategic Planning for discussions of choice of RNA, folding, and detection methods.

\section{Additional Materials (also see Basic Protocol 1)}

$\geq 97 \%$ diethylpyrocarbonate (DEPC) (store up to 1 year at $2^{\circ}$ to $8^{\circ} \mathrm{C}$ )

NOTE: DEPC is toxic. Handle with appropriate care.

3b. Add $1 \mu \mathrm{L}$ DEPC, mix, and incubate $45 \mathrm{~min}$ at room temperature.

\section{MODIFICATION AND CLEAVAGE OF RNA USING ETHYLNITROSOUREA}

Ethylnitrosourea (ENU) alkylates phosphate oxygens that are not involved in tertiary structure interactions. These include phosphates of both single-stranded and doublestranded nucleotides not participating in higher-ordered structure. Following alkaline treatment, the phosphotriester hydrolyzes resulting in RNA strand scission. See Strategic Planning for discussions of choice of RNA, folding, and detection methods.

\section{Additional Materials (also see Basic Protocol 1)}

ENU/ethanol solution (see recipe)

0.1 M Tris.Cl, pH 9.0 (APPENDIX 2A)

ALTERNATE PROTOCOL 2

Chemical and Enzymatic Probes for Nucleic Acid Structure 


\section{Alkylate phosphates}

1. Prepare reaction mix as follows:

$2 \mu \mathrm{L} 1$ M HEPES, pH 7.8 (final $200 \mathrm{mM}$ )

$1 \mu \mathrm{L} 1 \mathrm{M} \mathrm{KCl}(100 \mathrm{mM})$

$1 \mu \mathrm{L} 0.1 \mathrm{M} \mathrm{MgCl}_{2}(10 \mathrm{mM})$

$2 \mu \mathrm{L} 1 \mu \mathrm{g} / \mu \mathrm{L}$ carrier RNA $(0.2 \mu \mathrm{g} / \mu \mathrm{L})$

2. Combine 50,000 cpm end-labeled sample RNA or $0.5 \mu \mathrm{g}$ unlabeled sample RNA (for primer extension) with RNase-free water to make $3 \mu \mathrm{L}$ total and add to reaction mix.

3. Add $1 \mu \mathrm{L}$ of ENU/ethanol solution, mix, and incubate $30 \mathrm{~min}$ at room temperature.

4. Stop the reaction by precipitating with $1 \mu \mathrm{L}$ of $3 \mathrm{M}$ sodium acetate and $30 \mu \mathrm{L}$ of $100 \%$ ethanol on dry ice. Microcentrifuge $30 \mathrm{~min}$ at maximum speed (10,000 rpm), $4{ }^{\circ} \mathrm{C}$. Remove supernatant, rinse with $70 \%$ ethanol, and dry the pellet in a speedvac.

\section{Hydrolyze phosphotriesters}

5. Resuspend pellet in $10 \mu \mathrm{L}$ of $0.1 \mathrm{M}$ Tris. $\mathrm{Cl}, \mathrm{pH} 9.0$, and incubate $5 \mathrm{~min}$ at $50^{\circ} \mathrm{C}$.

6. Precipitate as in step 4.

7. If RNA has been end-labeled, resuspend in $12 \mu \mathrm{L}$ FEXS solution and proceed with gel electrophoresis (e.g., APPENDIX $3 B$ or CPMB UNIT 2.12). If RNA sample was not labeled, perform primer extension (see Support Protocol 4).

See Support Protocol 3 for preparation of appropriate end-labeled RNA standards for electrophoresis.

BASIC

PROTOCOL 2
Probing RNA

Structure with Chemical

Reagents and Enzymes

\section{CLEAVAGE OF RNA USING NUCLEASES}

Nucleases hydrolyze the RNA phosphodiester backbone resulting in strand scission. Cleavages can be identified using primer extension (see Support Protocol 4) or end-labeled RNA (see Support Protocol 1 and Support Protocol 2). Table 6.1.1 lists nuclease specificities and cleavage locations. Some nucleases use divalent metal cofactors to catalyze the reaction. Divalent-independent nucleases can be used to probe RNA in the presence and absence of divalent-dependent tertiary structures. Most nucleases are specific for single-stranded bases and require access to the base determinants for cleavage site recognition. Uncleaved nucleotide targets may be obscured from cleavage by tertiary structure or local steric hindrance.

Being relatively large, nucleases may not penetrate some RNA structures completely, and it is common for some potential targets to remain uncleaved. The data obtained from one nuclease will identify general structural trends (e.g., single- or double-stranded character), but often needs to be corroborated using additional nucleases or chemical probes. See Strategic Planning for discussions of choice of RNA, folding, and detection methods.

\section{Materials}

One of the following nucleases (see Table 6.1.1):

Mung bean nuclease

RNase A

RNase CL3

RNase I(ONE)

RNase Phy M

RNase T1 
RNase T2

RNase U2

RNase V1

S1 nuclease

0.1 M Tris.Cl, pH 7.5 (APPENDIX 2A)

$1 \mathrm{M} \mathrm{KCl}$ (APPENDIX 2A)

$0.1 \mathrm{M} \mathrm{MgCl}_{2}$

$1 \mu \mathrm{g} / \mu \mathrm{L}$ carrier RNA (see recipe)

Sample RNA, end labeled (see Support Protocol 1 or Support Protocol 2) or unlabeled

RNase-free water (see recipe)

$3 \mathrm{M}$ sodium acetate, $\mathrm{pH} 5.2$ (APPENDIX 2A)

$100 \%$ and $70 \%(\mathrm{v} / \mathrm{v})$ ethanol

FEXS solution (see recipe)

Additional reagents and equipment for direct gel electrophoresis (e.g., APPENDIX $3 B$ or CPMB UNIT 2.12) or primer extension (see Support Protocol 4)

1. Prepare six reaction tubes, each containing:

$1 \mu \mathrm{L} 0.1 \mathrm{M}$ Tris $\cdot \mathrm{Cl}$, pH 7.5 (final $10 \mathrm{mM}$ )

$1 \mu \mathrm{L} 1 \mathrm{M} \mathrm{KCl}(100 \mathrm{mM})$

$1 \mu \mathrm{L} 0.1 \mathrm{M} \mathrm{MgCl}_{2}(10 \mathrm{mM})$

$2 \mu \mathrm{L} 1 \mu \mathrm{g} / \mu \mathrm{L}$ carrier RNA $(0.2 \mu \mathrm{g} / \mu \mathrm{L})$.

2. For each reaction mix, combine $50,000 \mathrm{cpm}$ end-labeled sample RNA or $0.5 \mu \mathrm{g}$ unlabeled sample RNA (for primer extension) with RNase-free water to make $4 \mu \mathrm{L}$ total. Add to each reaction mix.

3. Dilute nuclease at six 5-fold serial dilutions (covering four orders of magnitude) with $10 \mathrm{mM}$ Tris. $\mathrm{Cl}$ to give the appropriate amounts in a volume of $1 \mu \mathrm{L}$. Dilute RNase V1 with $10 \mathrm{mM}$ Tris. $\mathrm{Cl}$ and $10 \mathrm{mM} \mathrm{MgCl} \mathrm{M}_{2}$.

Nuclease activity varies by lot and by manufacturer. Thus, it is necessary to titrate the amount of nuclease necessary to cleave $\sim 10 \%$ of the RNA of interest. A second titration consisting of narrower increments may be necessary once the desired activity is found. Table 6.1.2 lists activity units that have produced $10 \%$ cleavage using the reaction conditions described above. These should be used as guidelines only.

Table 6.1.2 Quantities of Nuclease That Achieve $\sim 10 \%$ Cleavage in $10 \mathrm{~min}$

\begin{tabular}{ll}
\hline Nuclease & Quantity $^{a}$ \\
\hline Mung bean nuclease & ND \\
RNase A & $0.2 \mathrm{ng}$ \\
RNase CL3 & $0.025-0.100 \mathrm{U}$ \\
RNase I(ONE) & $0.012 \mathrm{U}$ \\
RNase Phy M & $1.0 \mathrm{U}$ \\
RNase T1 & $0.138 \mathrm{U}$ \\
RNase T2 & ND \\
RNase U2 & $1.0 \mathrm{U}$ \\
RNase V1 & $0.047 \mathrm{U}$ \\
S1 nuclease & ND \\
\hline
\end{tabular}

$a_{\mathrm{ND}, \text { not determined }}$

Chemical and Enzymatic Probes for Nucleic Acid Structure 
SUPPORT PROTOCOL 1

Probing RNA Structure with Chemical

Reagents and Enzymes
Fresh nuclease dilutions should be used each time, although dilutions of RNases T1, A, and $I(O N E)$ can be frozen with minimal loss of activity.

4. Add $1 \mu \mathrm{L}$ of each nuclease dilution to a reaction mix, mix well, and incubate $10 \mathrm{~min}$ at room temperature.

5. Add $1 \mu \mathrm{L}$ of $3 \mathrm{M}$ sodium acetate and $30 \mu \mathrm{L}$ of $100 \%$ ethanol and precipitate on dry ice. Microcentrifuge $30 \mathrm{~min}$ at maximum speed $(10,000 \mathrm{rpm}), 4^{\circ} \mathrm{C}$. Remove supernatant, rinse with $70 \%$ ethanol, and dry the pellet in a speedvac.

6. If the RNA sample was end-labeled, resuspend in $12 \mu \mathrm{L}$ of FEXS solution and proceed with gel electrophoresis (e.g., APPENDIX $3 B$ or $C P M B$ UNIT 2.12). If sample RNA was not labeled, see Support Protocol 4 and perform primer extension.

See Support Protocol 3 for preparation of appropriate end-labeled RNA standards for electrophoresis.

\section{LABELING THE $5^{\prime}$ RNA TERMINUS USING T4 POLYNUCLEOTIDE KINASE AND $\left[\gamma-{ }^{32}\right.$ P $]$ ATP}

Bacteriophage T4 polynucleotide kinase will transfer the $\gamma$ phosphate of $\left[\gamma_{-}{ }^{32} \mathrm{P}\right] \mathrm{ATP}$ to an RNA substrate containing a $5^{\prime}$ hydroxyl group, or it will exchange the radiolabeled $\gamma$ phosphate with a single $5^{\prime}$ phosphate present on the RNA substrate. The $5^{\prime}$ end of cellular RNAs may contain methyl guanosine cap structures that prohibit labeling by this method. Chemical solid-phase synthesis produces an RNA with a $5^{\prime}$ hydroxyl available for radiolabeling using $\left[\gamma^{32} \mathrm{P}\right] \mathrm{ATP}$ and polynucleotide kinase, whereas RNA transcribed in vitro has a $5^{\prime}$ triphosphate that must first be removed with a phosphatase. Dephosphorylation is accomplished with bacterial alkaline phosphatase and its accompanying buffer. An alternate method, not described here, of generating $5^{\prime}$-labeled RNA by enzymatic synthesis is to transcribe in vitro with T7 RNA polymerase and $\left[\gamma_{-}{ }^{32} \mathrm{P}\right] \mathrm{GTP}$, incorporating ${ }^{32} \mathrm{P}$ at only the $5^{\prime}$ terminal triphosphate (Milligan and Uhlenbeck, 1989).

This protocol can also be used to produce $5^{\prime}$ end-labeled DNA oligomers to be used as primers in primer extension (see Support Protocol 4). This is done by performing the labeling reaction below (steps 8 to 11) with the appropriate DNA oligomer.

\section{Materials}

RNA of interest

$150 \mathrm{U} / \mu \mathrm{L}$ bacterial alkaline phosphatase (BAP; Life Technologies)

RNase-free water (see recipe)

10× dephosphorylation buffer: $100 \mathrm{mM}$ Tris. Cl, $\mathrm{pH} 8.0$ (APPENDIX 2A)

25:24:1 (v/v/v) phenol/chloroform/isoamyl alcohol (APPENDIX 2A)

$3 \mathrm{M}$ sodium acetate, $\mathrm{pH} 5.2$ (APPENDIX 2A)

$100 \%$ and $70 \%(\mathrm{v} / \mathrm{v})$ ethanol

$10 \mathrm{mM}$ EDTA (APPENDIX 2A)

$10 \times$ kinase buffer (see recipe)

$0.1 \mathrm{M}$ dithiothreitol (DTT)

$150 \mu \mathrm{Ci} / \mu \mathrm{L}\left[\gamma^{-}{ }^{32} \mathrm{P}\right] \mathrm{ATP}(6000 \mathrm{Ci} / \mathrm{mmol}$; NEN Life Sciences $)$

$10,000 \mathrm{U} / \mathrm{mL}$ T4 polynucleotide kinase

Stop mix (see recipe)

Water baths, $37^{\circ} \mathrm{C}$ and $90^{\circ}$ to $100^{\circ} \mathrm{C}$

Additional reagents and equipment for phenol/chloroform/isoamyl alcohol extraction (APPENDIX 2A) 
1. Calculate picomoles of RNA in $0.2 \mu \mathrm{g}$ and set up the following reaction mix:

$0.2 \mu \mathrm{g}$ RNA of interest

$10 \mu \mathrm{L}$ of $10 \times$ dephosphorylation buffer

RNase-free water to give $100 \mu \mathrm{L}$ final volume.

70 U BAP per picomole RNA(dilute with 1x dephosphorylation buffer if necessary)

Phosphate treatment is necessary if the RNA sample was generated by in vitro transcription.

See also supplier's technical bulletin for recommended reaction conditions.

2. Incubate $1 \mathrm{hr}$ at $65^{\circ} \mathrm{C}$.

3. Extract with $100 \mu \mathrm{L}$ of $25: 24: 1$ phenol/chloroform/isoamyl alcohol to stop the reaction.

4. Remove the aqueous phase to a new tube. Add $10 \mu \mathrm{L}$ of $3 \mathrm{M}$ sodium acetate and 300 $\mu \mathrm{L}$ of $100 \%$ ethanol. Precipitate on dry ice and then microcentrifuge $30 \mathrm{~min}$ at maximum speed $(10,000 \mathrm{rpm}), 4^{\circ} \mathrm{C}$. Remove supernatant, rinse with $70 \%$ ethanol, and dry the pellet in a speedvac.

5. Bring $0.2 \mu \mathrm{g}$ RNA to $18 \mu \mathrm{L}$ with RNase-free water.

\section{Denature RNA sample (optional)}

6. Add $2 \mu \mathrm{L}$ of $10 \mathrm{mM}$ EDTA. Heat $2 \mathrm{~min}$ at $90^{\circ}$ to $100^{\circ} \mathrm{C}$, then quickly transfer to an ice water bath and cool $5 \mathrm{~min}$.

Denaturation will increase labeling efficiency of base-paired or recessed $5^{\prime}$ termini; however, some RNA samples may be labeled more efficiently when folded.

7. Briefly microcentrifuge at maximum speed to collect any condensation.

\section{Label RNA}

8. Combine the following and incubate $1 \mathrm{hr}$ at $37^{\circ} \mathrm{C}$.

$13 \mu \mathrm{L}$ denatured RNA $(0.13 \mu \mathrm{g})$

$2 \mu \mathrm{L} 10 \times$ kinase buffer

\section{$2 \mu \mathrm{L} 0.1 \mathrm{M}$ DTT}

$2 \mu \mathrm{L}\left[\gamma^{32} \mathrm{P}\right] \mathrm{ATP}$

$1 \mu \mathrm{L}$ T4 polynucleotide kinase (10 U).

A crude preparation of $\left[\gamma^{32} P\right] A T P$ is sufficient for this reaction and is less expensive.

To label DNA primers, replace RNA with $\sim 1 \mu \mathrm{g}$ DNA oligomer and proceed through step 11 .

9. Add $4 \mu \mathrm{L}$ stop mix and $100 \mu \mathrm{L}$ of $100 \%$ ethanol (5 vol).

10. Precipitate on dry ice, then microcentrifuge $30 \mathrm{~min}$ at maximum speed $(10,000 \mathrm{rpm})$, $4^{\circ} \mathrm{C}$.

11. Carefully remove supernatant (very radioactive) and dry the pellet in a speedvac.

If the RNA is not going to be used immediately, resuspend the pellet in the appropriate buffer or water to reduce radiation-induced damage and freeze at $-80^{\circ} \mathrm{C}$. The length of time the RNA can be stored is limited by its activity; the half life of ${ }^{32} \mathrm{P}$ is 14 days. 
SUPPORT PROTOCOL 2
Probing RNA Structure with Chemical Reagents and Enzymes
12. If a heterogeneous population exists, purify the radiolabeled RNA by denaturing gel electrophoresis (APPENDIX 3B).

The RNA must have a discrete length to accurately identify nucleotide cleavages/modifications in the subsequent structure probing experiments.

\section{LABELING THE $3^{\prime}$ RNA TERMINUS USING T4 RNA LIGASE AND $\left[{ }^{32}\right.$ P $]$ pCp}

Bacteriophage T4 RNA ligase will catalyze phosphodiester formation between a nucleotide $3^{\prime}$ hydroxyl and a nucleotide 5' phosphate. The RNA of interest requires a 3' hydroxyl that will be coupled to $5^{\prime}-\left[{ }^{32} \mathrm{P}\right]$ cytidine- $3^{\prime}, 5^{\prime}$-bisphosphate $\left(\left[{ }^{32} \mathrm{P}\right] \mathrm{pCp}\right) .\left[{ }^{32} \mathrm{P}\right] \mathrm{pCp}$ can be purchased or generated using $3^{\prime}$-cytosine-monophosphate, $\left[\gamma^{-32} \mathrm{P}\right] \mathrm{ATP}$, and T4 polynucleotide kinase (England et al., 1980; UNIT 6.3). The latter method is recommended because it generates the concentrated form needed at a reasonable cost.

Enzymatically synthesized RNAs have a $3^{\prime}$ hydroxyl that can be directly ligated with radiolabeled $\left[{ }^{32} \mathrm{P}\right] \mathrm{pCp}$. Breakdown of RNA by nucleases, metal or alkaline hydrolysis, and cleavage by ribozymes (excluding RNase $\mathrm{P}$ ) produces $2^{\prime}-3^{\prime}$ cyclic phosphates, which subsequently hydrolyze to $3^{\prime}$ phosphates and cannot be directly $3^{\prime}$ end labeled. Dephosphorylation of $3^{\prime}$ phosphates is accomplished with bacterial alkaline phosphatase and accompanying buffer (see Support Protocol 1).

\section{Additional Materials (also see Support Protocol 1)}

$0.5 \mathrm{M}$ HEPES, pH 7.9 at $50 \mathrm{mM}$

$0.1 \mathrm{M} \mathrm{MgCl}_{2}$

$0.1 \mathrm{mg} / \mathrm{mL}$ bovine serum albumin (BSA)

$1 \mathrm{mM}$ ATP

Dimethyl sulfoxide (DMSO)

$500 \mu \mathrm{M} 5^{\prime}-\left[{ }^{32} \mathrm{P}\right]$ cytidine-3',5'-bisphosphate $\left(\left[{ }^{32} \mathrm{P}\right] \mathrm{pCp}\right.$; UNIT 6.3 or Amersham)

20 to $25 \mathrm{U} / \mu \mathrm{L}$ T4 RNA ligase

\section{Dephosphorylate RNA (optional)}

1. If necessary, dephosphorylate RNA as described (see Support Protocol 1, steps 1 to 4), but increase RNA to $2 \mu \mathrm{g}$ and increase BAP accordingly.

2. Resuspend pellet in $10 \mu \mathrm{L}$ RNase-free water to make $0.2 \mu \mathrm{g} / \mu \mathrm{L}(\sim 6 \mu \mathrm{M}$ for a 100-nucleotide RNA).

\section{Label RNA}

3. Mix the following (10 $\mu \mathrm{L}$ total volume):

$1 \mu \mathrm{L} 10 \mu \mathrm{M}$ RNA of interest (final $1 \mu \mathrm{M}$ )

$1 \mu \mathrm{L} 0.5 \mathrm{M}$ HEPES, pH 7.9 at $50 \mathrm{mM}(50 \mathrm{mM})$

$2 \mu \mathrm{L} 0.1 \mathrm{M} \mathrm{MgCl}_{2}(20 \mathrm{mM})$

$1 \mu \mathrm{L} 0.1 \mathrm{mg} / \mathrm{mL}$ BSA $(10 \mu \mathrm{g} / \mathrm{mL})$

$1 \mu \mathrm{L} 30 \mathrm{mM}$ DTT (3 mM)

$1 \mu \mathrm{L} 1 \mathrm{mM}$ ATP $(0.1 \mathrm{mM})$

$1 \mu \mathrm{L}$ DMSO (10\% v/v)

$1 \mu \mathrm{L} 500 \mu \mathrm{M}\left[{ }^{32} \mathrm{P}\right] \mathrm{pCp}(50 \mu \mathrm{M})$

$1 \mu \mathrm{L} 20$ to $25 \mathrm{U} / \mu \mathrm{L}$ T4 RNA ligase ( 2 to $2.5 \mathrm{U} / \mu \mathrm{L}$ )

4. Incubate $\geq 12 \mathrm{hr}$ at $4^{\circ} \mathrm{C}$ (typically overnight). 
5. Add $90 \mu \mathrm{L}$ RNase-free water, mix, and extract with $100 \mu \mathrm{L}$ of $25: 24: 1$ phenol/chloroform/isoamyl alcohol.

6. Add $10 \mu \mathrm{L}$ of $3 \mathrm{M}$ sodium acetate and $300 \mu \mathrm{L}$ of $100 \%$ ethanol.

7. Precipitate and purify as described (see Support Protocol 1, steps 10 to 12).

\section{PREPARING STANDARDS FOR ELECTROPHORESIS OF END-LABELED RNA CLEAVAGE PRODUCTS}

Limited alkaline hydrolysis and digestion with RNase T1 under denaturing conditions are used to prepare two separate sets of electrophoresis standards in order to determine sites of end-labeled RNA cleavage. Alkaline hydrolysis results in a relatively even ladder of truncated RNAs. A denaturing RNase T1 digest cleaves the RNA 3' of each guanosine. Comparison of the two products with the modified/cleaved end-labeled RNA after electrophoresis identifies guanosines along the alkaline hydrolysis ladder, and therefore the intervening products present in the alkaline hydrolysis reaction can be determined from the RNA sequence. End-labeled RNA cleavage products from structure-probing reactions can thus be identified.

\section{Materials}

RNA of interest, ${ }^{32} \mathrm{P}$-end-labeled to 50,000 cpm (see Support Protocol 1 or Support Protocol 2)

$100 \%$ (v/v) ethanol

$3 \mathrm{M}$ sodium acetate, $\mathrm{pH} 5.2$ (APPENDIX 2A)

$\mathrm{Na}_{2} \mathrm{CO}_{3} /$ EDTA solution (see recipe)

CU buffer (see recipe)

RNase T1 (Life Technologies)

$2 \mu \mathrm{g} / \mu \mathrm{L}$ tRNA carrier (see recipe for carrier RNA)

CEU buffer (see recipe)

FEXS solution (see recipe)

$95^{\circ} \mathrm{C}$ water bath

\section{Alkaline Hydrolysis of RNA}

1. Ethanol precipitate $50,000 \mathrm{cpm}$ of end-labeled RNA in $1 / 10 \mathrm{vol}$ of $3 \mathrm{M}$ sodium acetate, $\mathrm{pH} 5.2$ and $3 \mathrm{vol}$ of $100 \%$ ethanol, microcentrifuge $30 \mathrm{~min}$ at maximum speed, $4^{\circ} \mathrm{C}$ $(10,000 \mathrm{rpm})$, and dry the pellet in a speedvac.

2. Resuspend with $1.2 \mu \mathrm{L} \mathrm{Na}_{2} \mathrm{CO}_{3} /$ EDTA solution and mix with a pipet.

3. Incubate between 90 and $120 \mathrm{sec}$ at $95^{\circ} \mathrm{C}$, then $1 \mathrm{~min}$ on ice.

Initially, vary incubation time at $95^{\circ} \mathrm{C}$ to achieve a relatively even ladder of products following electrophoresis, thereafter use the most successful incubation time.

4. Add $2.8 \mu \mathrm{L}$ of CU buffer and mix to neutralize.

5. Add $8 \mu \mathrm{L}$ FEXS solution. Store frozen at $-80^{\circ} \mathrm{C}$, if necessary.

The time the RNA can be stored is dependent on the signal detection and the ${ }^{32} \mathrm{P}$ half life (14 days).

\section{RNase T1 Digest of RNA}

6. Add $5 \mu \mathrm{L}$ of $2 \mu \mathrm{g} / \mu \mathrm{L}$ carrier tRNA to a second aliquot of $50,000 \mathrm{cpm}$ end-labeled RNA. Ethanol precipitate with 1/10th vol $3 \mathrm{M}$ sodium acetate, and 3 vol 100\%
SUPPORT

PROTOCOL 3
Chemical and Enzymatic Probes for Nucleic Acid Structure 
ethanol, microcentrifuge $30 \mathrm{~min}$ at maximum speed $(10,000 \mathrm{rpm}), 4^{\circ} \mathrm{C}$, and dry the pellet in a speedvac.

7. Resuspend with $3 \mu \mathrm{L}$ CEU buffer and mix with a pipet.

8. Incubate $5 \mathrm{~min}$ at $50^{\circ} \mathrm{C}$.

9. Add $1 \mu \mathrm{L}$ RNase $\mathrm{T} 1$ diluted in $\mathrm{CEU}$ buffer and incubate $15 \mathrm{~min}$ at $50^{\circ} \mathrm{C}$.

The appropriate RNase T1 dilution will need to be determined by titration, but 1 to $3 \mathrm{U}$ typically produces good results.

Alternatively, other urea-tolerant nucleases, such as RNase A (C and U specific), can be used.

10. Add $8 \mu \mathrm{L}$ FEXS solution. Store frozen at $-80^{\circ} \mathrm{C}$, if necessary.

BASIC PROTOCOL 3
Probing RNA

Structure with Chemical

Reagents and Enzymes

\section{MODIFICATION OF RNA AT WATSON-CRICK POSITIONS USING DIMETHYL SULFATE}

Watson-Crick positions of adenosines (N1) and cytidines (N3) not involved in base pairing or tertiary-structure hydrogen bonding are alkylated by DMS. Primer extension (see Support Protocol 4) of modified RNA and comparison with dideoxynucleotide sequencing reactions identifies the modified bases. Used together, dimethyl sulfate (for A and C), kethoxal (for G; see Alternate Protocol 3), and CMCT (for U; see Alternate Protocol 4) provide a complete analysis of the base-pairing status (i.e., secondary structure) of the RNA of interest. See Strategic Planning for discussions of RNA sample source and folding.

\section{Materials}

0.5 M HEPES, $\mathrm{pH} 7.8$

$1 \mathrm{M} \mathrm{KCl}$ (APPENDIX 2A)

$0.1 \mathrm{M} \mathrm{MgCl}_{2}$

$1 \mu \mathrm{g} / \mu \mathrm{l}$ RNA of interest

RNase-free water (see recipe)

10.56 M dimethyl sulfate (DMS; 99+\%)

$100 \%$ and $70 \%(\mathrm{v} / \mathrm{v})$ ethanol

3 M sodium acetate, $\mathrm{pH} 5.2$ (APPENDIX 2A)

Additional reagents and equipment for primer extension (see Support Protocol 4)

CAUTION: DMS is highly toxic and a suspected carcinogen; appropriate precautions should be taken for handling, storage, and disposal.

1. Prepare four reaction tubes, each containing:

$1 \mu \mathrm{L}$ 0.5 M HEPES, pH 7.8 (final $50 \mathrm{mM}$ )

$1 \mu \mathrm{L} 1 \mathrm{M} \mathrm{KCl}(100 \mathrm{mM})$

$1 \mu \mathrm{L} 0.1 \mathrm{M} \mathrm{MgCl}_{2}(10 \mathrm{mM})$

$2 \mu \mathrm{L} 1 \mu \mathrm{g} / \mu \mathrm{L}$ RNA of interest $(0.2 \mu \mathrm{g} / \mu \mathrm{L})$

$4 \mu \mathrm{L}$ RNase-free water

2. Just prior to use, dilute DMS in four 2-fold serial dilutions in $100 \%$ ethanol to give the appropriate amounts in a volume of $1 \mu \mathrm{L}$. 
DMS must initially be titrated to attain the desired RNA modification typically $\sim 10 \%$. The following dilutions are provided as examples only. Dilute $1 \mu \mathrm{L}$ of $10.56 \mathrm{M}$ DMS stock in $16.6 \mu \mathrm{L}$ of $100 \%$ ethanol to give $600 \mathrm{mM}$. Further dilute 2-, 4-, and 8-fold with 100\% ethanol to make 300,150 , and $75 \mathrm{mM}$ dilutions, respectively. The final reaction concentrations will be 60, 30, 15, and $7.5 \mathrm{mM}$.

3. Add $1 \mu \mathrm{L}$ of each DMS dilution to a reaction mix, mix well, and incubate $20 \mathrm{~min}$ at room temperature.

4. Add $1 \mu \mathrm{L}$ of $3 \mathrm{M}$ sodium acetate and $30 \mu \mathrm{L}$ of $100 \%$ ethanol and precipitate on dry ice. Microcentrifuge $30 \mathrm{~min}$ at maximum speed $(10,000 \mathrm{rpm}), 4^{\circ} \mathrm{C}$. Remove supernatant, rinse with $70 \%$ ethanol, and dry the pellet in a speedvac.

5. Resuspend pellet in $40 \mu \mathrm{L}$ RNase-free water and proceed with primer extension (see Support Protocol 4$)$ using $4 \mu \mathrm{L}(0.2 \mu \mathrm{g})$ per reaction.

\section{MODIFICATION OF RNA AT WATSON-CRICK POSITIONS USING KETHOXAL}

Kethoxal alkylates the $\mathrm{N} 1$ and 2- $\mathrm{NH}_{2}$ Watson-Crick positions of guanosines not involved in base pairing or tertiary-structure hydrogen bonding. The procedure is the same as for modification with DMS (see Basic Protocol 3), except that step 2 is replaced with the following step. Used together, dimethyl sulfate (A \& C; Basic Protocol 3), kethoxal (G), and CMCT (U; Alternate Protocol 4) provide a complete analysis of the base-pairing status (i.e., secondary structure) of the RNA of interest. See Strategic Planning for discussion of RNA sample source and folding.

\section{Additional Materials (also see Basic Protocol 3)}

\subsection{M kethoxal stock (ICN or Research Organics)}

2b. Just prior to use, dilute 4.27 M kethoxal in four 2-fold serial dilutions in RNase-free water to give the appropriate amounts in a volume of $1 \mu \mathrm{L}$.

Kethoxal must be titrated to attain the desired RNA modification. The following dilutions are provided as examples only.

Dilute $1 \mu \mathrm{L}$ of 4.27 M kethoxal stock in $20.35 \mu \mathrm{L}$ water to give $200 \mathrm{mM}$. Further dilute 2-, 4-, and 8-fold with water to make 100, 50, and $25 \mathrm{mM}$ dilutions, respectively. Final reaction concentrations will be 20,10,5, and $2.5 \mathrm{mM}$.

\section{MODIFICATION OF RNA AT WATSON-CRICK POSITIONS USING CMCT}

1-Cyclohexyl-3-(2-morpholinoethyl)carbodiimide metho- $p$-toluenesulfonate (CMCT) alkylates the N3 Watson-Crick position of uridines not involved in base pairing or tertiary-structure hydrogen bonding. The approach is essentially as described for modification with DMS (see Basic Protocol 3), except that the reactions are performed as outlined below. Used together, dimethyl sulfate (A \& C; Basic Protocol 3), kethoxal (G; Alternate Protocol 3), and CMCT (U) provide a complete analysis of the base-pairing status (i.e., secondary structure) of the RNA of interest. See Strategic Planning for discussion of RNA sample source and folding.

\section{Additional Materials (also see Basic Protocol 3)}

$0.5 \mathrm{M}$ potassium borate, $\mathrm{pH} 8.0$

0.5 M 1-cyclohexyl-3-(2-morpholinoethyl)carbodiimide metho- $p$-toluenesulfonate

(CMCT) in RNase-free $\mathrm{H}_{2} \mathrm{O}$ (stable for several weeks at $-20^{\circ} \mathrm{C}$; Aldrich)

$37^{\circ} \mathrm{C}$ water bath
ALTERNATE PROTOCOL 3

ALTERNATE PROTOCOL 4

Chemical and Enzymatic Probes for Nucleic Acid Structure 
1. Prepare three reaction tubes, each containing:

$1 \mu \mathrm{L} 0.5 \mathrm{M}$ potassium borate, $\mathrm{pH} 8.0$ (final $50 \mathrm{mM}$ )

$1 \mu \mathrm{L} 1 \mathrm{M} \mathrm{KCl}(100 \mathrm{mM})$

$1 \mu \mathrm{L} 0.1 \mathrm{M} \mathrm{MgCl}_{2}(10 \mathrm{mM})$

$2 \mu \mathrm{L} 1 \mu \mathrm{g} / \mu \mathrm{L}$ RNA of interest $(0.2 \mu \mathrm{g} / \mu \mathrm{L})$

2. Just prior to use, heat $0.5 \mathrm{M} \mathrm{CMCT}$ at $37^{\circ} \mathrm{C}$ and vortex to ensure the reagent is completely solubilized. Immediately dilute $0.5 \mathrm{M} \mathrm{CMCT}$ solution to $200 \mathrm{mM}$ and 50 $\mathrm{mM}$ in RNase-free water.

CMCT must be titrated to attain the desired RNA modification. The above dilutions can be used for the initial titration. Final reaction concentrations using the stock solution and the two dilutions will be 250,100 , and $25 \mathrm{mM}$, respectively.

3. Add $5 \mu \mathrm{L}$ of each CMCT dilution to a reaction mix, mix well, and incubate $20 \mathrm{~min}$ at room temperature.

4. Precipitate and proceed to primer extension as described (see Basic Protocol 3, steps 4 and 5).

SUPPORT PROTOCOL 4

Probing RNA Structure with Chemical

Reagents and Enzymes

\section{DETECTION OF RNA CLEAVAGE OR MODIFICATION BY PRIMER EXTENSION}

Primer extension of a radiolabeled DNA oligomer will synthesize a complementary DNA strand to the RNA of interest. Reverse transcriptase will stop upon encountering alkylated Watson-Crick determinants, resulting in a product one base short of the modification. The enzyme will also run off RNA cleavage products, producing a DNA corresponding to the site of cleavage. Strong secondary structure, such as hairpin loops within the RNA, can cause the enzyme to pause, creating a prematurely terminated product. It is therefore essential to perform the reaction on unmodified/uncleaved RNA as a control. This enables pause sites from secondary structure to be subtracted from the modification/cleavage analysis. Because carrier RNA can affect the reverse transcription reaction, control reactions should include the carrier RNA as well. The reaction requires a DNA oligomer complementary to the RNA of interest, $3^{\prime}$ of the region to be examined. It might be necessary to use several DNA oligomers to examine an RNA several hundred nucleotides long. The extension products are resolved on standard DNA sequencing gels, allowing -200 nucleotides to be examined per DNA primer. Location of primer-extension terminations is determined by comparison to standard dideoxynucleotide sequencing reactions using the same primer and a template of the same sequence as the RNA being examined.

The primer-extension reaction requires a ${ }^{32} \mathrm{P}$-labeled DNA oligomer that is generated using bacteriophage T4 polynucleotide kinase. Reaction conditions for labeling the primer are identical to those used for end labeling the $5^{\prime}$ RNA terminus (see Support Protocol 1), but substituting the DNA oligomer for the RNA.

\section{Materials}

$\left[5^{\prime}-{ }^{32} \mathrm{P}\right] \mathrm{DNA}$ oligomer (see Support Protocol 1) complementary to $3^{\prime}$ end of the sample RNA

Sample RNA, cleaved or modified (see Basic Protocols 1 to 3 and Alternate

Protocols 1 to 4)

RNase-free water (see recipe)

Sample RNA, uncleaved and unmodified

$25 \mathrm{mM}$ 4dNTP mix (see dNTPs in APPENDIX 2A)

$0.1 \mathrm{M}$ dithiothreitol (DTT) 
$5 \times$ first strand buffer (see recipe)

200 U/ $\mu \mathrm{L}$ Superscript II RNase H(-) Moloney murine leukemia virus reverse transcriptase (MMLV RT; Life Technologies; see Troubleshooting for alternative RTs)

$3 \mathrm{M}$ sodium acetate, $\mathrm{pH} 5.2$ (APPENDIX 2A)

$100 \%$ and $70 \%(\mathrm{v} / \mathrm{v})$ ethanol

FENXB solution (see recipe)

Dideoxynucleotide sequencing reactions (e.g., CPMB UNIT 7.4A) of cDNA for sample RNA

Sequencing gel: $6 \%(\mathrm{w} / \mathrm{v})$ acrylamide (20:1 mono-/bis-), $8 \mathrm{M}$ urea, $1 \times$ TBE buffer (APPENDIX $2 A$ for TBE buffer)

Water bath or heating block, $42^{\circ}$ and $70^{\circ} \mathrm{C}$

Additional reagents and equipment for running a sequencing gel (APPENDIX $3 B$ )

\section{Anneal primer}

1. Mix the following:

$100,000 \mathrm{cpm}\left[5^{\prime}-{ }^{32} \mathrm{P}\right] \mathrm{DNA}$ oligomer

$0.2 \mu \mathrm{g}$ sample RNA, cleaved or modified

RNase-free water to $18.5 \mu \mathrm{L}$.

It may be necessary to titrate the $\left[{ }^{32} P\right] D N A$ oligomer and RNA concentrations to optimize the extension reaction conditions.

2. Set up a similar control reaction using unmodified, uncleaved RNA.

This control should be performed to identify structure-induced terminations and to ensure that the majority of the DNA oligomer is being fully extended through the region of interest.

3. Incubate $10 \mathrm{~min}$ at $70^{\circ} \mathrm{C}$, followed by $30 \mathrm{~min}$ at $42^{\circ} \mathrm{C}$.

4. Briefly microcentrifuge down any condensation that forms.

\section{Extend DNA}

5. To the primer/RNA mix add:

$3 \mu \mathrm{L} 25 \mathrm{mM} 4 \mathrm{dNTP}$ mix

\section{$2 \mu \mathrm{L} 0.1 \mathrm{M}$ DTT}

$6 \mu \mathrm{L} 5 \times$ first strand buffer.

Total volume is now $29.5 \mu \mathrm{L}$.

6. Add $0.5 \mu \mathrm{L}$ (100 U) Superscript II and mix.

7. Incubate $45 \mathrm{~min}$ at $42^{\circ} \mathrm{C}$.

8. Add $3 \mu \mathrm{L}$ of $3 \mathrm{M}$ sodium acetate, and $90 \mu \mathrm{L}$ of $100 \%$ ethanol. Precipitate on dry ice and microcentrifuge $30 \mathrm{~min}$ at maximum speed $(10,000 \mathrm{rpm}), 4^{\circ} \mathrm{C}$.

9. Remove supernatant, rinse pellet with $70 \%$ ethanol, and dry the pellet in a speedvac.

10. Resuspend in $6 \mu \mathrm{L}$ FENXB solution for resolution on a $6 \%$ acrylamide sequencing gel (APPENDIX $3 B)$. Use dideoxynucleotide sequencing reactions as markers (e.g., CPMB Unit 7.4A).

Typically a cDNA template, rather than an RNA template, is used for the sequencing reactions, allowing them to be performed with a DNA-dependent DNA polymerase (e.g., Sequenase; United States Biochemical). 


\section{REAGENTS AND SOLUTIONS}

Use deionized water in all recipes and protocol steps. For common stock solutions, see APPENDIX 2A; for suppliers, see SUPPLIERS APPENDIX.

\section{Aniline acetate buffer, $1 \mathrm{M}$}

$10 \mu \mathrm{L}$ of $99.5 \%$ aniline

$93 \mu \mathrm{L} \mathrm{H} \mathrm{H}_{2} \mathrm{O}$

$6 \mu \mathrm{L}$ glacial acetic acid

Make fresh

CAUTION: Aniline is highly toxic.

\section{Carrier RNA, $1 \mu g / \mu L$ or $2 \mu g / \mu L$}

Carrier RNA can be unlabeled RNA of interest or total yeast tRNA. Extract yeast tRNA with 25:24:1 (v/v/v) phenol/chloroform/isoamyl alcohol (APPENDIX 2A) and ethanol precipitate to remove any protein contaminants. Store at $-20^{\circ} \mathrm{C}$.

\section{Citrate/EDTA/urea (CEU) buffer}

For $100 \mathrm{~mL}$ :

$10.25 \mathrm{~mL} 0.1 \mathrm{M}$ citric acid

$14.75 \mathrm{~mL} 0.1 \mathrm{M}$ sodium citrate (final $25 \mathrm{mM}$ citrate)

$0.2 \mathrm{~mL}$ 0.5 M EDTA (APPENDIX 2A; final $1 \mathrm{mM}$ )

$\sim 30 \mathrm{~mL} \mathrm{H}_{2} \mathrm{O}$

$42.04 \mathrm{~g}$ urea (final $7 \mathrm{M}$ )

Adjust to $\mathrm{pH} 4.7$ to 5.0 with $\mathrm{HCl}$

Stable indefinitely at $-20^{\circ} \mathrm{C}$

\section{Citrate/urea $(\mathrm{CU})$ buffer}

For $100 \mathrm{~mL}$ :

$10.25 \mathrm{~mL} 0.1 \mathrm{M}$ citric acid

$14.75 \mathrm{~mL} 0.1 \mathrm{M}$ sodium citrate (final $25 \mathrm{mM}$ citrate)

$\sim 30 \mathrm{~mL}$ of $\mathrm{H}_{2} \mathrm{O}$

$60.06 \mathrm{~g}$ urea (10 M final)

Adjust to $\mathrm{pH} 4.7$ to 5.0 with $\mathrm{HCl}$

Stable indefinitely at $-20^{\circ} \mathrm{C}$

\section{Ethylnitrosourea $($ ENU)/ethanol solution}

Add $N$-nitroso- $N$-ethylurea (ENU) to $100 \mu \mathrm{L}$ of $100 \%$ ethanol until solution is saturated. Centrifuge to pellet insoluble reagent. Make fresh.

CAUTION: ENU is highly toxic and a suspected carcinogen. follow appropriate precautions for handling, storage, and disposal.

\section{FENXB solution}

95\% formamide, redistilled

$20 \mathrm{mM}$ EDTA (APPENDIX 2A)

$2 \mathrm{mM} \mathrm{NaOH}$

$0.05 \%$ xylene cyanol

$0.05 \%$ bromphenol blue

Stable indefinitely at -5 to $-20^{\circ} \mathrm{C}$

Probing RNA

Structure with

Chemical

Reagents and Enzymes

\section{FEXS solution}

95\% formamide, redistilled

10 mM EDTA (APPENDIX 2A)

$0.05 \%$ xylene cyanol

$0.1 \%$ SDS

Stable indefinitely at -5 to $-20^{\circ} \mathrm{C}$ 
First strand buffer, 5×

$250 \mathrm{mM}$ Tris. $\mathrm{Cl}, \mathrm{pH} 8.3$ (APPENDIX 2A)

$375 \mathrm{mM} \mathrm{KCl}$

$15 \mathrm{mM} \mathrm{MgCl} 2$

Stable indefinitely at $-20^{\circ} \mathrm{C}$

Kinase buffer, 10 $\times$

$700 \mathrm{mM}$ Tris.Cl, $\mathrm{pH} 7.6$ (APPENDIX 2A)

$100 \mathrm{mM} \mathrm{MgCl} 2$

$50 \mathrm{mM}$ dithiothreitol (DTT)

Stable indefinitely at $-20^{\circ} \mathrm{C}$

$\mathrm{Na}_{2} \mathrm{CO}_{3} /$ EDTA solution

For $1 \mathrm{~mL}$ :

$50 \mu \mathrm{L} 1 \mathrm{M} \mathrm{Na}_{2} \mathrm{CO}_{3}$, pH 11.7 (final $50 \mathrm{mM}$ )

$2 \mu \mathrm{L} 0.5 \mathrm{M}$ EDTA (APPENDIX $2 A$; final $1 \mathrm{mM}$ )

$948 \mu \mathrm{L} \mathrm{H}_{2} \mathrm{O}$

Stable indefinitely at $-20^{\circ} \mathrm{C}$

Stop mix

20 mM EDTA (APPENDIX 2A)

$0.3 \mathrm{M} \mathrm{NaCl}$

$1 \mu \mathrm{g} / \mu \mathrm{L}$ glycogen

Stable indefinitely at $-20^{\circ} \mathrm{C}$

Water, RNase free

Test water source for contaminating nuclease activity by incubating labeled RNA in water and buffers for intended reaction time. Ascertain integrity of sample by electrophoresis. Often deionized and glass-distilled water will be free of nucleases. However, if water and/or buffer reagents contain nuclease activity, treat with DEPC to inactivate (APPENDIX 2A).

Autoclaved solutions are sometimes allowed to stand at room temperature, with loose caps, for several days to remove all DEPC. Trace DEPC can inhibit reverse transcriptase and other enzymes.

\section{COMMENTARY}

\section{Background Information}

Sensitivity to chemical and enzymatic reagents can often be used to test hypotheses regarding solution exposure and singlestranded versus double-stranded character along the folded RNA chain; however, the data generated in these experiments is most effective when used in reference to a secondary structure model for the RNA generated by other approaches. Computer-based energy-minimization algorithms have proven extremely useful in predicting simple RNA structures or in providing multiple local folding possibilities in larger RNAs (Zuker, 1989; Gautheret et al., 1990; Major et al., 1991; Malhotra et al., 1993; Walter et al., 1994; Gorodkin et al., 1997). These folding algorithms suffer from several severe limitations in predicting longer RNAs, however, tending to miss long-distance interactions and lacking sufficient predictions of nonstandard interactions among nucleotides. In some instances, the physiologically relevant RNAs will also contain nucleoside modifications that are not necessarily known or taken into account. Perhaps most importantly, the functional form of the molecules might not be the most stable folded form under the conditions used to fold the RNA in vitro. It is possible that manipulation of the folding conditions might identify methods that drive the majority of a purified RNA into an appropriate structure, assuming that there is some method to determine what constitutes an appropriate structure.
Chemical and Enzymatic Probes for Nucleic Acid Structure 
Manipulation of folding conditions for RNAs synthesized in vitro will be discussed below.

Structural analysis of RNAs and ribonucleoproteins (RNPs) can be used to determine secondary structure, facilitate modeling of tertiary structure, and identify RNA-protein contacts. The source of the material to be probed will often dictate which labeling and probing techniques are necessary. Primer extension is the preferred method for analysis of large or cellularly derived RNAs. The native RNA or RNP complex can be assayed without manipulations that may disrupt the integrity of the sample. Postmodification or cleavage products are assayed by extension of labeled DNA oligomers with reverse transcriptase. End labeling techniques can also sometimes be successful. However, in vivo-derived RNAs often possess $5^{\prime}$ methyl cap structures preventing labeling at that terminus, and one or both termini in the native RNA can be recessed or obscured by protein in RNP structures. Chemical or enzymatic synthesis of RNA permits incorporation of labeling groups during synthesis, or if necessary, labeling sites can be engineered in the synthetic RNAs. Studies involving novel sequences, subregions of larger RNAs, or RNP reconstitution experiments sometimes require the use of synthetic RNA. Chemical and enzymatic synthesis of RNA also provides an opportunity to incorporate nucleosides modified with fluorescent, antigenic, or crosslinking groups during synthesis.

\section{Critical Parameters}

The first principle in RNA structure analysis is to begin with an RNA properly folded into its physiologically relevant structure. Synthetic RNA may or may not be in its properly folded state. Gentle purification techniques should retain the in vivo conformation of cellularly derived RNAs and RNPs. However, folding of many RNAs in vivo is not readily reproduced in vitro, in many instances because the RNAs require association of proteins to assume physiologically appropriate structures. In these cases it might be necessary to either isolate the RNAs from cells or to associate the appropriate proteins in vitro in a manner that can be demonstrated to cause the RNA to assume a functional structure. The best insurance that the RNA or RNP of interest is correctly folded is to test its functional or enzymatic activity. Other folding assays will be necessary if no functional assay exists.

The number of folding isoforms of an RNA sample can sometimes be determined using native polyacrylamide gel electrophoresis. RNAs with extensive self-complementarity often form multimers, which can be detected on the native gel. Heat denaturation can be used to melt present structures. Cooling rate, RNA concentration, and the presence of mono- and divalent cations all affect the subsequent folding isoform populations. In general, a faster cooling rate, the absence of cations, and low RNA concentrations favor intramolecular folding. Likewise, slow cooling in high salt with high RNA concentrations favors intermolecular folding and the formation of multimers.

It should be noted that the RNA might need to adopt more than one structure to carry out its function(s) in vivo. Driving all of the RNA sample (or protein-RNA complex) into a single form might reflect only one aspect of the functional RNA structure.

Once the RNA is properly folded, the structure-probing experiments can begin. There are four factors that are key to experiment reproducibility. The first is a consistent reaction mix. Make a batch of all ingredients minus the reagent, mix, then aliquot to the necessary number of tubes. Always make enough for the desired number of reactions plus one. This will ensure that the amount of each component, especially radiolabeled RNA, is identical between reactions. The second factor is reaction time. Many of the probing reactions are short (e.g., $10 \mathrm{~min}$ ) to minimize the effect of any contaminating nuclease activity. The number of reactions attempted at once should not compromise strict adherence to the reaction time. Longer reaction times may be used effectively, but short times have been found to reduce secondary or nonspecific activities. The third factor is the use of unlabeled carrier RNA. Carrier RNA provides a constant substrate concentration for the probing reagents. The concentration of radiolabeled RNA is much less than the carrier and is negligible in most reactions. Therefore, any changes in labeling efficiency between RNA preparations will have little effect. Lastly, it is necessary to titrate the amount of reagent for each particular RNA of interest so that $\sim 10 \%$ of the RNA is cleaved. The likelihood of multiple cleavages per molecule is thereby reduced. Typically, the concentration of RNA is held constant and the amount of reagent is titrated until the desired extent of modification is achieved. If the RNA sample of interest is extremely limited, reagents are titrated using a different RNA with the identical unlabeled carrier RNA and buffer conditions. 
The presence of excess carrier RNA facilitates reproducibility of cleavage conditions.

\section{Troubleshooting}

Primer-extension analysis of probing reactions can encounter several pitfalls. For example, breakdown in the sample results in termination products not produced by the probing reagents. Extension of unmodified, uncleaved RNA should identify these sites and allow for their subtraction from the probing data. However, extensive degradation or strong secondary structure-induced terminations may obscure cleavages or modifications at several nucleotides of interest. Synthetic RNA sample integrity can be improved by changing the original purification strategy or by further purification to ensure that a discrete population exists. RNA samples in crude cellular fractions should be prepared as rapidly as possible at $0^{\circ}$ to $4^{\circ} \mathrm{C}$ and stored frozen $\left(-80^{\circ} \mathrm{C}\right)$ when not in use to minimize degradation by endogenous nucleases. To alleviate secondary structure-induced terminations, the primer-extension reaction conditions and/or the reverse transcriptase can be changed. Superscript II has demonstrated an ability to proceed quite well through secondary structure, but other reverse transcriptases, such as AMV and Retrotherm, may function better on a particular RNA. The heat-stable Retrotherm can also be used at elevated temperatures to minimize RNA secondary structure.

Achieving an interpretable amount of modification or cleavage is another problem often encountered. The desired modification or cleavage goal is $10 \%$ of the total RNA, in the realm of single-hit kinetics. This rule minimizes the presence of products resulting from multiple modifications or cleavages. Typically, the concentration of reagent is adjusted until the $10 \%$ goal is reached for a batch of RNA, carrier RNA, and reagent. Single cleavages or modifications per RNA molecule usually allow for detection of all available targets within the region of interest. However, a hyper-reactive site may exist that prevents further primer extension or observation of end-labeled RNA products larger than the hyper-reactive nucleotide. In this scenario, a new primer complementary to the region $5^{\prime}$ of the RNA modification will be needed, or in the case of end-labeled RNA, labeling the opposite end will allow analysis of the remaining RNA region of interest.

All of the probing reactions are purposefully designed to have nearly identical buffer and salt conditions. RNA structure can change consid- erably based on the amount and nature of counterions and $\mathrm{pH}$. Consistency in reaction conditions between different probing reagents helps to ensure the same structure is being examined. The buffers and $\mathrm{pH}$ are changed only when they may interfere with the chemical nature of the reagent. It should be noted that the maximal activities of several reagents and most of the nucleases occur under different conditions than those listed, but all have been used successfully as described. The standard salt conditions can be altered as desired but consistency is important. Also, formation of RNA tertiary structures is often very dependent on the amount and type of counter-ions present.

Uncharacteristic modifications or cleavages from probing reagents are sometimes observed. Interpretation of atypical activities should be regarded with appropriate caution. For example, reagents used outside their optimal reaction conditions or the presence of contaminating activities could be responsible. It is also possible to observe inconsistencies between reagents with the same targets. Thus, using two reagents that should cleave or modify an unpaired nucleotide might give the result that the nucleotide is sensitive to one but not the other. In all probability, the reagents are functioning properly, but subtle differences in substrate binding and recognition can favor one over the other.

\section{Anticipated Results}

There are several cautionary notes that should be considered when interpreting RNA footprinting data. First, it should always be remembered that both purified RNAs and RNA-protein complexes can exist in multiple isoforms, whether folded and bound in vitro or isolated intact from cells. As far as possible, the heterogeneity of RNA sample of interest should be investigated and taken into account when interpreting sensitivity. Second, sensitivity to cleavage or modification reagents is far more useful in showing solution exposure than "protection" from reagents. Inaccessibility of even the same region of a base to an individual enzyme or chemical can vary from reagent to reagent, and can have a number of causes including involvement in hydrogen bonding, folding into the interior of the RNA where it is less exposed to the solvent, inappropriate chemical states, and direct blockage by interacting proteins. Thus, if protection is observed in a particular region when a protein is added, the protection might result from either direct coverage by the protein or indirect effects of
Chemical and Enzymatic Probes for Nucleic Acid Structure 
the bound protein acting at a distance. It should be reemphasized that even detailed footprinting results are often consistent with multiple hypothetical structures, and for any complex RNA it is likely that additional, independent types of evidence will be needed to sort out the possibilities.

Results of structure-probing experiments are useful to qualitatively model RNA structure. The more reagents employed, the more descriptive the analysis. Suspected anomalous modifications or cleavages by a single reagent can therefore be subtracted. Modification/cleavage products can be quantitated by phosphorimager analysis and analyzed using a computer (e.g., ImageQuant from Molecular Dynamics; visual inspection of autoradiograms is fine for qualitative analysis). The accessibility of an RNA target is directly proportional to the modification/cleavage product band intensity. End-labeled RNA or labeled primer-extension products have one label per product molecule. However, it is not simple to interpret the reason that one target is preferred over another. Targets on the surface of a molecule are likely to be more accessible than those buried within the interior of a tertiary structure, although local steric effects may have as much impact on reagent reactivity as global structure. Data obtained using multiple reagents will better uncover the true solution structure of a target, and the trend of several reagents should be regarded as the rule, rather than a single hit by one reagent. One should also keep in mind that solution structure is dynamic and that RNA molecular motion is dependent on temperature and ionic environment.

\section{Time Considerations}

The design of structure-probing experiments is dictated by the stability of the RNA sample of interest and the half-life of radiolabeled material. Cellularly derived RNAs or RNPs often contain contaminating nuclease activities, and these can be considerable depending on the purification scheme employed. It is therefore imperative to preserve samples frozen at $-80^{\circ} \mathrm{C}$ and to use them immediately upon thawing. Synthetic RNAs are often free of contaminating nucleases, depending on the handling and manipulations the sample has received. The structure-probing reactions are usually short (e.g., $10 \mathrm{~min}$ ) to reduce the effects of any contaminating activities. Control reactions should identify extraneous cleavages, provided that the majority of the sample is not degraded in the reaction interval. A time course incubation of the RNA of interest in the desired reaction buffer may prove beneficial in identifying sample integrity versus incubation time. Longer reaction times, allowing for more samples, might then be used.

Modified/cleaved RNA intended for primerextension analysis can be stored frozen at $-80^{\circ} \mathrm{C}$ while the radiolabeled DNA primer is made. End-labeled RNA should be resolved by electrophoresis promptly after modification/cleavage reactions are complete. Note that only $10 \%$ of the RNA sample should be modified/cleaved; therefore, the detectable radiolabel signal from the modified/cleaved products will only be $10 \%$ of the sample's specific activity. Experiments should proceed readily to maximize signal from a batch of radiolabeled RNA.

Once all reaction components are in hand, setting up the probing reactions, incubating, and terminating the reactions for a single reagent should take $\sim 1$ to $3 \mathrm{hr}$. Primer extension typically takes 2 to $3 \mathrm{hr}$, and gel electrophoresis on standard sequencing $(6 \%)$ polyacrylamide gels requires 2 to $3 \mathrm{hr}$.

\section{Literature Cited}

England, T., Bruce, A., and Uhlenbeck, O. 1980. Specific labeling of $3^{\prime}$ termini of RNA with T4 RNA ligase. Methods Enzymol. 65:65-74.

Gautheret, D., Major, F., and Cedergren, R. 1990. Computer modeling and display of RNA secondary and tertiary structures. Methods Enzymol. 183:318-330.

Gorodkin, J., Heyer, L., and Stormo, G. 1997. Finding the most significant common sequence and structure motifs in a set of RNA sequences. Nucl. Acids Res. 25:3724-3732.

Knapp, G. 1989. Enzymatic approaches to probing of RNA secondary and tertiary structure. Methods Enzymol. 180:192-212.

Krol, A. and Carbon, P. 1989. A guide for probing native small nuclear RNA and ribonucleoprotein structures. Methods Enzymol. 180:212-227.

Major, F., Turcotte, M., Gautheret, D., Lapalme, G., Fillion, E., and Cedergren, R. 1991. The combination of symbolic and numerical computation for three-dimensional modeling of RNA. Science 253:1255-1260.

Malhotra, A., Gabb, H., and Harvey, S. 1993. Modeling large nucleic acids. Curr. Opin. Struct. Biol. 3:241-246.

Milligan, J.F. and Uhlenbeck, O.C. 1989. Synthesis of small RNAs using T7 RNA polymerase. Methods Enzymol. 180:51-62.

Peattie, D.A. and Gilbert, W. 1980. Chemical probes for higher-order structure in RNA. Proc. Natl. Acad. Sci. U.S.A. 77:4679-4682. 
Walter, A.E., Turner, D.H., Kim, J., Lyttle, M.H., Muller, P., Matthews, D.H., and Zuker, M. 1994.

Coaxial stacking of helixes enhances binding of oligoribonucleotides and improves predictions of RNA folding. Proc. Natl. Acad. Sci. U.S.A. 91:9218-9222.

Zuker, M. 1989. On finding all suboptimal foldings of an RNA molecule. Science 244:48-52.
Contributed by William A. Ziehler and

David R. Engelke

University of Michigan

Ann Arbor, Michigan
Chemical and

Enzymatic Probes for Nucleic Acid

Structure 